\title{
Cancer Evaluation in Geriatric Population: A Single Institution Experience
}

\author{
Fatma P. TURKOZ, Saadet TOKLUOGLU, Ayse G. DURNALI, Arife ULAS, Erkan ARPACI, \\ Tarkan YETISYIGIT, Gokhan CELENKOGLU, Necati ALKIS
}

Ankara Oncology Training and Research Hospital, Department of 1. Medical Oncology, Ankara, TURKEY

\begin{abstract}
Increasing life expectancy and increasing cancer incidence with aging will result in expansion of the elderly cancer population. Cancer epidemiology trials of patients aged 70 years or older are very rare in the literature and only subgroup analysis are presented. The objective of our study was to evaluate the cancer distribution, rates and trends in geriatric population. 90,472 patients with cancer diagnosis, who were admitted to our hospital between January 2005 and December 2009, were identified through a search in the hospital-based computer database, retrospectively. 9682 (10.7\%) patients aged 70 years or older were analyzed for social-demographic characteristics, cancer distribution, rates and trends. 4,954 male (51.2\%) and 4,728 female (48.8\%) patients, age ranged from 70 to 96 years, with a median age of 75 years were analyzed. Ten leading cancer types were breast (15.8\%), prostate (9.9\%), colorectal $(9.6 \%)$, lung (9.4\%), skin (6.7\%), gastric (6.6\%), bladder (6.3\%), nonhodgkin lymphoma (4.7\%), over (2.8\%) and endometrium (2.7\%) in elderly. The number of new cancer cases significantly increased by years, for both men and women $(p<$ 0.001). Cancers of gastrointestinal tract, lung, breast, head-neck and skin showed significant increasing trends $(p<0.001)$; whereas brain, gynecologic and urinary tract cancers had stable trends in both sexes ( $p>0.05)$. In conclusion, a comprehensive cancer statistic in geriatric population will be decisive in determining the health policies. Breast, cervical, colorectal and prostate cancers are the types of cancer for which early screening has been shown to reduce mortality. Cancer screening should be attentively applied in elderly patients.
\end{abstract}

Keywords: Cancer, Elderly, Geriatry

\section{ÖZET}

\section{Geriatrik Popülasyonda Kanser Değerlendirmesi: Tek Merkez Deneyimi}

Yaşam süresinin uzaması ve kanser insidansının yaşla birlikte artması, gelecekte yaşı kanser popülasyonunun büyümesi ile sonuçlanacaktır. 70 yaş ve üzeri hastalarda kanser epidemiyoloji çalısmaları literatürde çok nadir olup, veriler yalnızca alt grup analizleri şeklinde sunulmaktadır. Çalışmamızda geriatrik popülasyondaki kanser dağıııı, oranı ve arış hızı araştıııdı. Çalışmamızda Ocak 2005 Aralık 2009 tarihleri arasında hastanemize başvuran, kanser tanısıyla izlenen 90.472 erişkin hastanın verileri bilgisayardan retrospektif olarak incelendi. Tanı alma yaşı 70 yaş ve üzerinde olan 9682 (\%10.7) hastada sosyodemografik özellikler, kanser dağılımı, oranı ve artış hızı analiz edildi. Hastaların 4954'ü erkek (\% 51.2), 4728'i kadın (\% 48.8); medyan yaş 75 (70-96) yıldı. En sık görülen on kanser tipi meme (\% 15.8), prostat (\%9.9), kolorektal (\%9.6), akciğer (\% 9.4), deri (\% 6.7), mide (\% 6.6), mesane (\% 6.3), nonhodgkin Ienfoma (\%4.7), over (\%2.8) ve endometrium (\%2.7) olarak bulundu. Yeni kanser vakalarının hem kadın hem de erkeklerde arttığı saptandı ( $p<0.001)$. Gastrointestinal sistem, akciğer, meme, baş-boyun ve deri kanserleri her iki cinste de giderek artış gösterirken $(p<$ 0.001), beyin, jinekolojik ve genitoüriner sistem kanserlerinin ylllar içerisinde istikrarlı bir seyir izlediği gözlendi ( $p>0.05)$. Sonuç olarak, geriatrik popülasyonda kapsamlı bir kanser istatistiği sağlık politikalarında belirleyici olacaktır. Meme, serviks, kolorektal ve prostat kanserleri erken tarama ile mortalitenin azaldığı gösterilen kanserlerdir. Kanser taramaları yaşllırda da özenle uygulanmalıdır.

Anahtar Kelimeler: Kanser, Yaşı, Geriatri 


\section{INTRODUCTION}

Increasing life expectancy and increasing cancer incidence with aging will result in expansion of the elderly cancer population. ${ }^{1}$ According to estimates from the International Agency for Research on Cancer, there were 12.7 million new cancer cases in 2008 worldwide and the global burden is expected to grow to 21.4 million new cancer cases and 13.2 million cancer deaths simply due to the growth and aging of the population, by $2030 .^{2}$ The percentage of Turkish population aged 65 years or over was 4.3 $\%$ in 1990 , it has risen to $5.7 \%$ in 2000 and to $7.2 \%$ in 2010. The overall cancer incidence rates were increased from 113.0 to 169.9 per 100.000 in women and 154.1 to 275.4 per 100.000 in men between 2002 and 2008, in Turkey. ${ }^{3}$

Approximately $60 \%$ of all new cancer cases and $70 \%$ of all cancer-related deaths occur beyond the age of 70 years. ${ }^{4}$ The cellular and molecular alterations in immune and endocrine system, tissue accumulation of cells in late stages of carcinogenesis, age-related telomere instability, loss of regenerative ability and apoptosis are the major mechanisms leading to cancer susceptibility in elderly. ${ }^{5}$ Aging is associated with a progressive reduction in the functional reserve of multiple organ systems. ${ }^{6}$

Aging is highly individualized and chronologic age may not reflect the functional reserve, the physiologic, medical, emotional, or cognitive changes and life expectancy. A comprehensive geriatric assessment (CGA) including; activities of daily living, cognitive, emotional and social status, the number and severity of comorbid conditions, the number of medications and risk of drug interactions, nutritional assessment, presence of geriatric syndromes (dementia, delirium, depression, falls, spontaneous bone fractures, neglect and abuse) should be peformed before cancer management. ${ }^{6,7}$ The treatment of the older patient with cancer, should be aimed to maximize the benefits and minimize the risk of treatment in individual situations. ${ }^{6,8}$ Despite being at greatest risk, elderly are often under-represented in clinical trials of new cancer treatments. On the other hand, several studies have been shown that elderly patients with cancer experienced similar benefits from treatment and the toxicity rates were not higher than young cases. ${ }^{8}$
Cancer epidemiology trials of patients aged 70 years or older are very rare in the literature. The objective of our study was to evaluate the cancer distrubition, rates and trends in geriatric population, so to obtain a clinical approach for cancer management in elderly patients.

\section{PATIENTS AND METHODS}

In this study, 90.472 patients with cancer diagnosis who were admitted with a first diagnosis of cancer at Ankara Oncology Teaching and Research Hospital between January 1, 2005 and December 31, 2009; identified through a search of hospital-based computer database retrospectively. Age, sex, type of cancer, year of diagnosis, cancer site and initial admission were recorded. 9682 patients aged 70 years or older analysed for cancer distrubition, rates and trends. Statistical analysis was performed using SPSS software (version 15.0, SPSS, Inc.). One-way analysis of variance (ANOVA) was used to compare the means, followed by the Scheffé post hoc test. The annual rates of new cancer cases were given as mean values. Pearson's chi-square test was used for the comparison of percentages of new cancer cases diagnosed each year. A p value less than 0.05 was considered statistically significant.

\section{RESULTS}

A total of $9682(10.7 \%)$ patients aged $\geq 70$ years (range, 70 to 96 years) with a median age of 75 years were enrolled to the study. There were 4954 male $(51.2 \%)$ and 4728 female patients $(48.8 \%)$. Most common types of cancer were those affecting the gastrointestinal (GI) tract $(20.1 \%)$, genitourinary (GU) tract $(18.2 \%)$, breast $(16.3 \%)$, lung $(9.5 \%)$ and female genital tract $(8.3 \%)$.

Common cancer sites were GI tract in the seventh decades, GU tract and skin in the eighth decades and skin in the ninth decades. The patients with skin cancer were significantly older than all patients (mean age; 77 years, $p=0.02$ ). $0.5 \%$ of all breast cancer patients were diagnosed over the age of 90 years. $90.4 \%$ of our patients had a chance of treatment (surgery, chemotherapy, radiotherapy) at admission. Only $3.3 \%$ of patients needed palliative and supportive care. 


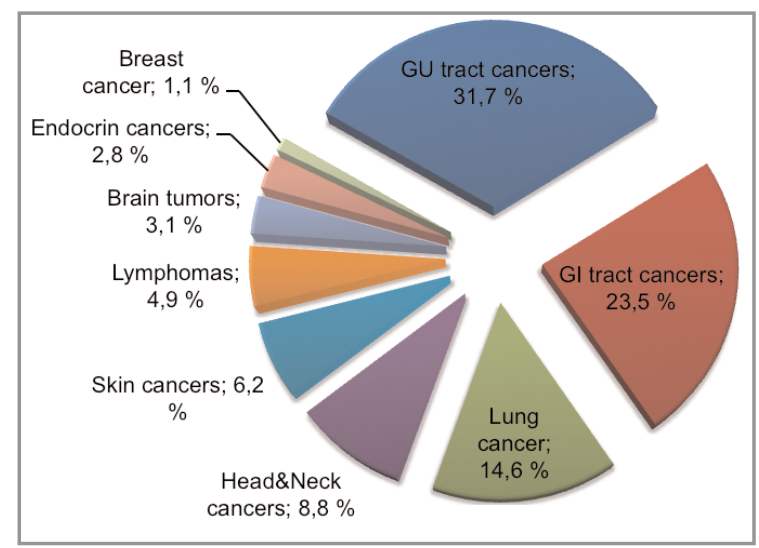

Graphic 1. Common cancer sites in elderly men

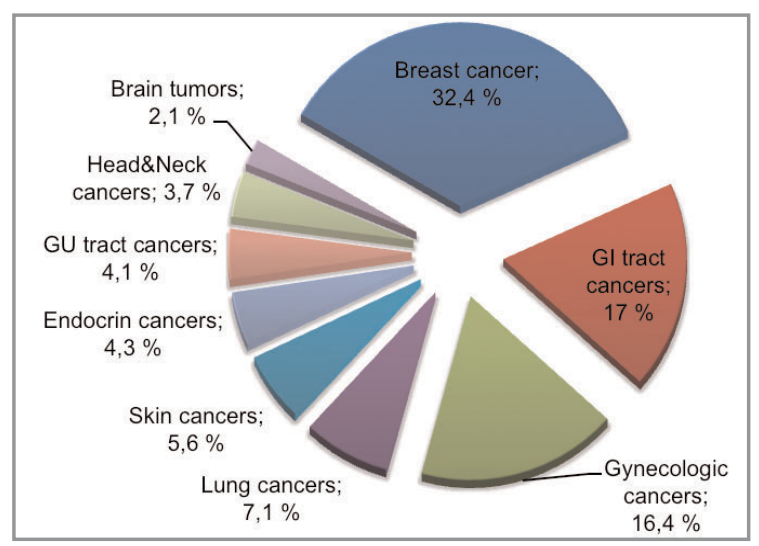

Graphic 2. Common cancer sites in elderly women

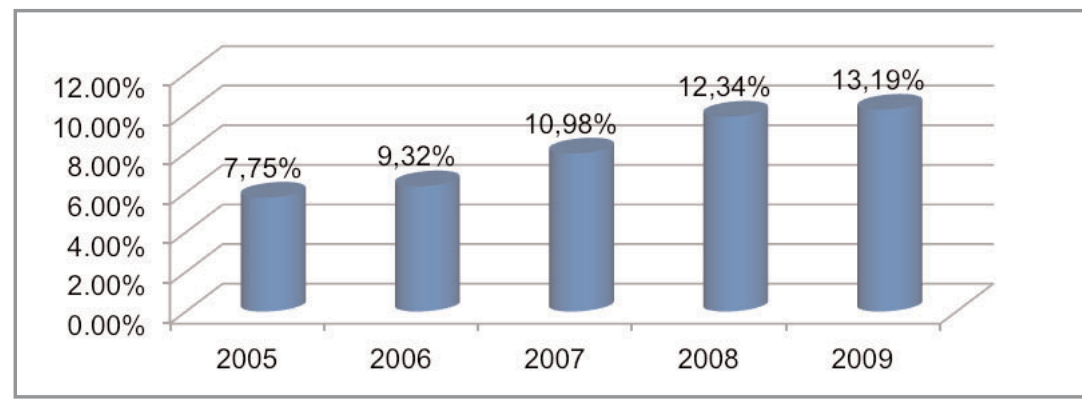

Graphic 3. The ratio of $\geq 70$ year-old patients to all patients in 5-year follow-up

Ten leading cancer types were breast (15.8\%), prostate $(9.9 \%)$, colorectal $(9.6 \%)$, lung $(9.4 \%)$, skin (6.7\%), gastric (6.6\%), bladder (6.3\%), nonhodgkin lymphoma (4.7\%), over (2.8\%) and endometrium $(2.7 \%)$ in elderly. Cancer of unknown primary (CUP) (0.6\%) was the rarest type. CUP was more frequent in men (male/female: 1.3/1) and multiple primary cancers were more frequent in women (fe- male/male: 1.4/1). The common cancer sites in men and women were given in graphics 1 and 2 .

The number of new cancer cases as well as the ratio of elderly patients to all patients were significantly increased between 2005 and 2009, for both men and women $(\mathrm{p}<0.001$ and $\mathrm{p}=0.002$, respectively) (Graphic 3).

\begin{tabular}{|llllll|}
\hline \multicolumn{3}{|l|}{ Table 1. Trends in new cancer cases } \\
$\begin{array}{l}\text { Site of } \\
\text { cancer }\end{array}$ & $\begin{array}{l}\text { Number } \\
\text { of patients }\end{array}$ & $\begin{array}{l}\text { Male/ } \\
\text { Female } \\
\text { ratio }\end{array}$ & $\begin{array}{l}\text { Mean age } \\
\text { (years) }\end{array}$ & $\begin{array}{l}\text { Increasing rate } \\
\text { (per year) }\end{array}$ & Common types of cancer \\
\hline Breast & 1583 & $1 / 29.4$ & $75.2 \pm 4.3$ & 2.27 - fold & \\
Lung & 919 & $3.7 / 1$ & $74.4 \pm 3.8$ & $1.99-$ fold & Non-small cell $80.9 \%$ \\
Skin & 646 & $1 / 1.09$ & $77.4 \pm 4.9$ & $1.95-$ fold & Nonmelanoma skin cancers $79 \%$ \\
Head\&Neck & 572 & $3.2 / 1$ & $75 \pm 4.6$ & $1.80-$ fold & Larinx 40.2\% \\
Gl tract & 1943 & $1.5 / 1$ & $75.1 \pm 4.1$ & $1.18-$ fold & Gastric 31.8\%; colon 27.9\%; rectum 19.8\% \\
GU tract & 1763 & $8.1 / 1$ & $75.2 \pm 4.1$ & Stable & Prostate 58.1\%; bladder 30.4\% \\
Gynecologic & 805 & - & $74.9 \pm 4.2$ & Stable & Ovarian 33.2\%; endometrium 32.7\%; cervix 28.1\% \\
Lymphomas & 507 & $1 / 1.1$ & $74.9 \pm 3.9$ & Stable & Non-hodgkin lymphoma $91.1 \%$ \\
\hline
\end{tabular}


Cancers of GI tract, lung, breast, head and neck and skin showed a significant inceasing trend $(\mathrm{p}<$ 0.001 ) whereas brain, gynecologic and GU tract cancers had a stable trend in both sexes $(\mathrm{p}>0.05)$. The number of endocrin system cancers decreased 0.8 -fold per year $(\mathrm{p}<0.01)$ and CUP also decreased 0.7 -fold but was not statistically significant ( $\mathrm{p}>$ 0.05 ). The patient characteristics and cancer increasing rates were shown in Table 1 .

\section{DISCUSSION}

Overall, there are 10.9 million new cases, 6.7 million deaths, and 24.6 million persons alive with cancer. $53.4 \%$ of these are male and $46.6 \%$ are female [9]. The most common cancers are lung (12.4\%), breast $(10.6 \%)$, colorectal $(9.4 \%)$, gastric $(8.6 \%)$ and prostate $(6.2 \%)$ in the world. ${ }^{10}$ Our study consisted of 4954 male patients $(51,2 \%)$ and 4728 female patients $(48,8 \%)$. Cancer was more common in men. Ten leading cancer types were breast $(15.8 \%)$, prostate $(9.9 \%)$, colorectal $(9.6 \%)$, lung $(9.4 \%)$, skin $(6.7 \%)$, gastric $(6.6 \%)$, bladder $(6.3$ $\%)$, nonhodgkin lymphoma $(4.7 \%)$, over $(2.8 \%)$ and endometrium $(2.7 \%)$ in elderly. Prostate $(16.9 \%)$, breast $(15.5 \%)$ and lung $(12.6 \%)$ cancers are frequently seen in America, on the other hand, lung $(14.5 \%)$, colorectal $(12.8 \%)$, breast $(12.3 \%)$, prostate $(11 \%)$ and gastric $(7.9 \%)$ cancers are common in Europe..$^{11,12}$ It is estimated that 7.4 million people died of cancer in 2004 and, if current trends continue, 83.2 million more will have died by 2015. ${ }^{4}$ According to the report prepared by the Turkish Ministry of Health, the overall cancer death rate was $10.1 \%$ in 1990 in Turkey, this figure increased to $14.8 \%$ in 2010 and continues to rise, as in many countries. ${ }^{3,13}$ We found a significant increase in the number of new cancer cases by years, for both men and women $(\mathrm{p}<0.001)$.

Among women, breast cancer is the most common cause of cancer mortality, accounting for $16 \%$ of cancer deaths in adult women. ${ }^{4}$ In our study, the most common type of cancer in women aged 70 years or older was breast cancer $(32.4 \%)$ followed by GI tract and gynecologic cancers. According to the report of the Turkish Ministry of Health, the agestandardized incidence rate of the most common cancers were; breast (125.9/100.000), colorectal (90.6/100.000) and gastric cancer (66.1/100.000) among women aged 70 years or over in $2008 .{ }^{3}$ In our study, the number of breast cancer cases was found to increase 2.27-fold per year $(p<0.001)$. This increasing trend may be due to an increase in the number of older patients, on the other hand, may also reflect the increased screening rates and diagnosis. It was reported that, the number of mammography for breast cancer screening and the number of pap-smear examinations performed for cervical cancer screening have increased approximately 2fold between 2007 and 2010, in our country. ${ }^{3}$

The greatest risk factor for prostate cancer is age. In our study, the most common type of cancer in men aged 70 years or older was prostate cancer $(21.7 \%)$, however, according to the report of the Turkish Ministry of Health, the age-standardized incidence rate of the most common cancers were; lung (528.0/100.000), prostate $(430.6 / 100.000)$ and urinary bladder cancer (195.6/100.000) among men aged 70 years or over in 2008. ${ }^{3}$ The number of deaths from prostate cancer has increased by around $16 \%$ since 1995 due to the increase in the numbers of men reaching older ages in Europe. While the decrease in prostate cancer death rates in America, has been attributed mainly to improved treatment, the increase in Asian and Eastern European countries has been thought to reflect westernization, including increased consumption of animal fat, obesity, and physical inactivity. ${ }^{14}$ The American Cancer Society (ACS) recommends that men who are at average risk of prostate cancer, and have a life expectancy of at least 10 years should be offered annual PSA testing and digital rectal examination beginning at age $50 .{ }^{15}$ In this study, prostate cancers were found to have a stable trend in last 5 years $(\mathrm{p}>$ $0.05)$.

Colorectal cancer incidence rates vary worldwide, with rates per 100,000 , among males in the time period 1998-2002 reported to range from 4.1 to 59.1 ; among females these rates ranged from 3.6 to 39.5 . The majority of registries with the highest incidence rates of colorectal cancer were located in Europe, and North America. The decrease in colorectal cancer incidence in the United States partially reflects the increase in detection and removal of precancerous lesions; the increase in several Asian and Eastern European countries may reflect changes in risk factors for colorectal cancer that are associated 
with westernization such as elevated obesity and smoking prevalence. ${ }^{16}$ In our study population; the most common cancer site was GI tract $(20.1 \%)$ and, the most common type was colorectal cancer $(47.7 \%)$. The male to female ratio was $1.3 / 1$. According to the report of Turkish Cancer Statistics (TCS); the incidence rates of colorectal cancers were slightly higher in men than in women and reported as 3.18 per $100.000 .{ }^{13}$ Colorectal cancer (8\%) was denoted as the third leading site of cancer death in the report of ACS. ${ }^{17}$ Colorectal cancer is estimated that the worldwide mortality rate was $1.1 \%$ in 2004, and will be $1.9 \%$ in $2030 .{ }^{4}$ In this study, the number of colorectal cancers was found to increase 1.18 -fold per year in elderly patients $(\mathrm{p}<0.001)$. Increasing colorectal cancer incidence may illustrate a lack of colorectal cancer screening programs and interventions to reduce the effects of lifestyle and dietary changes in patients. Unfortunately, opportunistic screening for colorectal cancer is not widely carried out in elderly patients.

The second most common type of GI tract cancer was gastric cancer $(31.8 \%)$ in this study. Gastric cancer is the second most common cancer, after lung cancer in men $(7.5 \%)$ and after breast cancer in women $(6.2 \%)$ according to report of TCS. ${ }^{13}$ It is also the second most common cause of cancer-related death worldwide with an estimated rate of $1.4 \%$ in 2004 and $1.9 \%$ in $2030 .{ }^{4}$ We established a significant increase by 1.18 -fold per year in the number of gastric cancer with colorectal cancer ( $\mathrm{p}<0.001)$. Our findings were consisted with WHO, 2008 reports.

Lung cancer was reported as the second most common type of cancer in men followed by prostate cancer, and the fourth most common cancer in women in ACS report. ${ }^{17}$ According to the report of TCS, lung cancer is the most common cancer with an incidence of $15.68 / 100.000$ among men. ${ }^{13}$ Cigarette smoking is the most important risk factor for lung cancer, accounting for about $80 \%$ of lung cancer cases in men and 50\% in women worldwide [18]. Lung cancer represents $13 \%$ of all cancer diagnoses and $30.4 \%$ of all cancer deaths and the worldwide mortality rate is estimated to increase to $3.6 \%$ in $2030{ }^{4,17}$ In a subgroup analysis of an epidemiological trial from Turkey, lung cancer was reported as the third most common type of cancer in patient aged 70 years or older. ${ }^{19}$ In our study, lung cancer was denoted as the third most common cancer in men and the fourth most common cancer in women. It was found to increase 1.99-fold (2.04fold in men and 1.84-fold in women) per year ( $\mathrm{p}<$ $0.001)$.

According to the report of TCS, skin cancer is the fifth most common cancer for females $(5.9 \%)$ and sixth most common cancer for males $(5.1 \%))^{13} \mathrm{In}$ our study, skin cancer was the fifth most common cancer in elderly. Several studies have reported that the incidence of primary skin cancer is increasing worldwide.$^{20}$ In this study, skin cancer was found to increase 1.95 -fold in last 5 years $(\mathrm{p}<0.001)$. These tendencies can be attributed to increased exposure of skin to UV radiation caused by lengthened life span and increased outdoor leisure hours, growing public understanding about skin cancer, and increased contact to various carcinogens in the food and environment. We determined malign melonama in $15 \%$ of all skin cancer patients. The incidence of malignant melanoma has been rising steadily in Europe and America, while showing a stable trend in Asia. $^{21}$

The world population dynamics will continue to age and, cancer will become a greater public health problem worldwide. A comprehensive cancer statistic in elderly will be decisive in determining the health policies. Breast, cervical and colorectal cancers are the types for which early screening has been shown to reduce mortality from the disease. ${ }^{22}$ Cancer screening programmes should be attentively applied in elderly patients.

\section{REFERENCES}

1. Extermann M, Aapro M, Bernabei R, et al. Use of comprehensive geriatric assessment in older cancer patients: recommendations from the task force on CGA of the International Society of Geriatric Oncology (SIOG). Crit Rev Oncol Hematol 55: 241-252, 2005.

2. Ferlay J, Shin HR, Bray F, et al. GLOBO-CAN 2008, Cancer Incidence and Mortality Worldwide: IARC Cancer-Base No.10 [Internet]. Lyon, France: International Agency for Research on Cancer. 2010; Available from: http://globocan.iarc.fr.

3. The Ministry of Health of Turkey, Health Statistics Yearbook 2010. Republic of Turkey, Ministry of Health, Refik Saydam Hygiene Center Presidency, School of Public Health, Ankara, 2011. 
4. World Health Statistics 2008, World Health Organization. Available at http://www.who.int/gho/publications/world_health_statistics. Access date:03.06.2012.

5. Anisimov VN. The relationship between aging and carcinogenesis: a critical appraisal. Crit Rev Oncol Hematol 45: 277-304, 2003.

6. Balducci L, Extermann M. Management of cancer in the older person: a practical approach. Oncologist 5: 224-237, 2000.

7. Extermann M, Aapro M. Assessment of the older cancer patient. Hematol Oncol Clin North Am 14: 63-77, 2000.

8. Bostankolu O, Oztürk B, Coskun U, Büyükberber $\mathrm{S}$, Benekli M. Yaşlı Hastalarda Kanser Kemoterapisi. UHOD 18: 186-192, 2008.

9. Ma X, Yu H. Global Burden of Cancer. Yale J Biol Med 79: 85-94, 2006.

10. Parkin DM, Bray F, Ferlay J, Pisani P. Global cancer statistics, 2002. CA Cancer J Clin 55: 74-108, 2005.

11. Jemal A, Siegel R, Ward E, et al. Cancer Statistics, 2008. CA Cancer J Clin 58: 71-96, 2008.

12. Bray F, Sankila R, Ferlay J, Parkin DM. Estimates of cancer incidence and mortality in Europe in 1995. Eur J Cancer 38: 99-166, 2002.

13. Cancer statistics, 2005, Turkey. The Ministry of Health of Turkey, Cancer Control Department, Ankara, 2006.

14. Ferlay J, Autier P, Boniol M, et al. Estimates of the cancer incidence and mortality in Europe in 2006. Ann Oncol 18: 581-92, 2007.

15. Wolf AM, Wender RC, Etzioni RB, et al. American Cancer Society guideline for the early detection of prostate cancer: update 2010. CA Cancer J Clin 60: 70-98, 2010.

16. Center MM, Jemal A, Smith RA, Ward E. Worldwide variations in colorectal cancer. CA Cancer J Clin 59: 366-378, 2009.

17. American Cancer Society. Global Cancer Facts \& Figures 2nd Edition. Atlanta: American Cancer Society; 2011.

18. Mackay J, Jemal A, Lee NC, Parkin DM. The Cancer Atlas. Atlanta: American Cancer Society; 2006.
19. Alıcı S, Izmirli M, Dogan E. Epidemiologic evaluation of the patients admitted to Department of Medical Oncology, Yuzuncu Yil University. Turk J Oncol 21: 8797, 2006.

20. Seo PG, Moon SE, Cho KH. A statistical study of cutaneous malignant tumors (1996-2000). Korean J Dermatol 40:129-137, 2002.

21. Qiu D, Marugame T. Comparison of Time Trends in Skin Cancer Incidence (1973-1997) in East Asia, Europe and USA, from Cancer Incidence in Five Continents Vol. IV-VIII. Jpn J Clin Oncol 38: 234-236, 2008.

22. American Cancer Society Guidelines for the Early Detection of Cancer. Avaible at http://www.cancer.org/healthy/findcancerearly/cancerscreeningguidelines. Access date:03.06.2012.

\section{Correspondence}

Dr. Fatma Paksoy TÜRKÖZ

Ankara Onkoloji Eğitim ve Araştırma Hastanesi

1. Tibbi Onkoloji Bölümü

13. Cadde, No: 56

Yenimahalle, ANKARA / TURKEY

Tel: (+90.505) 7509550

Fax: (+90.312) 3853857

e-mail: ftm.pksy@gmail.com 